\title{
Pursuing an understanding of animal consciousness: Implications for animal morality and a creaturely theology
}

\begin{tabular}{|c|c|}
\hline $\begin{array}{l}\text { Author: } \\
\text { Cornel W. du }\end{array}$ & Toit $^{1}$ \\
\hline $\begin{array}{l}\text { Affiliation: } \\
{ }^{1} \text { Research Inst } \\
\text { Theology and } \\
\text { University of S } \\
\text { South Africa }\end{array}$ & $\begin{array}{l}\text { itute for } \\
\text { Religion, } \\
\text { jouth Africa, }\end{array}$ \\
\hline $\begin{array}{l}\text { Corresponden } \\
\text { Cornel du Toit }\end{array}$ & ce to: \\
\hline $\begin{array}{l}\text { Email: } \\
\text { dtoitcw@unis }\end{array}$ & a.ac.za \\
\hline $\begin{array}{l}\text { Postal addres } \\
\text { PO Box } 392, \text { U } \\
\text { South Africa } 0 \\
\text { South Africa }\end{array}$ & $\begin{array}{l}\text { s: } \\
\text { niversity of } \\
003\end{array}$ \\
\hline $\begin{array}{l}\text { Dates: } \\
\text { Received: } 27 \mathrm{~F} \\
\text { Accepted: } 01 \\
\text { Published: } 21\end{array}$ & $\begin{array}{l}\text { eb. } 2015 \\
\text { July } 2015 \\
\text { Sept. } 2015\end{array}$ \\
\hline $\begin{array}{l}\text { How to cite th } \\
\text { Du Toit, C.W., } \\
\text { an understano } \\
\text { consciousness } \\
\text { for animal mo } \\
\text { creaturely the } \\
\text { et Ecclesia } 36( \\
10 \text { pages. http } \\
\text { org/10.4102/ }\end{array}$ & $\begin{array}{l}\text { is article: } \\
2015, \text { 'Pursuing } \\
\text { ling of animal } \\
\text { : Implications } \\
\text { rality and a } \\
\text { ology', Verbum } \\
\text { 3), Art. \#1442, } \\
\text { ://dx.doi. } \\
\text { /e.v36i3.1442 }\end{array}$ \\
\hline $\begin{array}{l}\text { Note: } \\
\text { This article rep } \\
\text { a theological } \\
\text { on the Faculty } \\
\text { Theme (FRT) } \\
\text { of Theology, } \\
\text { Pretoria, entit } \\
\text { Life in its fulln } \\
\text { theme is portr } \\
\text { the perspectiv } \\
\text { theological dis } \\
\text { A conference } \\
\text { was held on } 2 \\
2014 \text {. }\end{array}$ & $\begin{array}{l}\text { oresents } \\
\text { eflection } \\
\text { Research } \\
\text { f the Faculty } \\
\text { niversity of } \\
\text { led Ecodomy - } \\
\text { ess. The } \\
\text { ayed from } \\
\text { e of various } \\
\text { ciplines. } \\
\text { on this theme } \\
\text { 7-28 October }\end{array}$ \\
\hline $\begin{array}{l}\text { Copyright: } \\
\text { (C) 2015. The A } \\
\text { Licensee: AOS } \\
\text { OpenJournals. } \\
\text { licensed unde } \\
\text { Commons Attr }\end{array}$ & $\begin{array}{l}\text { ISthors. } \\
\text { IS } \\
\text { This work is } \\
\text { the Creative } \\
\text { ibution License. }\end{array}$ \\
\hline 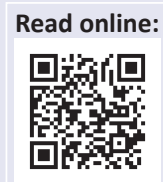 & $\begin{array}{l}\text { Scan this QR } \\
\text { code with your } \\
\text { smart phone or } \\
\text { mobile device } \\
\text { to read online. }\end{array}$ \\
\hline
\end{tabular}

Author:

Cornel W du Toit

Theology and Religion,

University of South Africa,

Correspondence to

Email:

South Africa 0003

w to cite this article: consciousness: Implications animal morality and a et Ecclesia 36(3), Art. \#1442, 10 pages. http://dx.doi. on the Faculty Research

Theme (FRT) of the Faculty of Theology, University of

Pretoria, entitled Ecodom

the perspective of various

theological disciplines.

(C) 2015. The Authors.

Licensee: AOSIS

licensed under the Creative

Read online:
The importance of animals in the evolutionary history of homo sapiens comes to the fore in light of an increasingly trans-human techno-scientific environment. New research on consciousness, and animal consciousness in particular, has prompted questions relating to animal rights, animal morality and the emergence of a creaturely theology and theological primatology. The possibility of understanding nonhuman animals is investigated with reference to notions like consciousness, thinking, awareness, language and communication, including the importance of emotion in communication. Special attention is given to the nature of animal communication as it came to the fore in bonobo and other chimpanzee research. Building on the notion of awareness and communication, the article focuses on the notion of animal morality and comments on some aspects of a creaturely theology.

\section{Introduction}

Animals are an important key to understanding what makes us human. True humanity is perhaps not possible in the absence of animals. Living with animals is a uniquely human trait, since no other mammals live intimately with other species and it probably developed over thousands of years - about 2.6 million years according to Shipman's estimate (2011:12ff.). Roughly 30 million years ago, baboons, chimpanzees, and humans shared the same ancestor (Cheney \& Seyfarth 2007:278).

However, we are in danger of losing this important link with animals that developed over millions of years. Animals are seemingly becoming less important to the very essence of being human. It is interesting to note that the introduction to philosophical anthropology usually devotes much time in defining humans by differentiating them from animals. Some of the differences between humans and animals that are emphasised include higher intelligence, human consciousness, language, morals and religion. Humans can do things that are impossible for animals. Homo habilis, the oldest toolmaker, is 2.6 million years old. From making tools, humans evolved to develop culture, grow crops, advance technology, and change their environment to suit them. (There are a few exceptions: the idea of a beaver and bee culture; some animals use 'tools' to get to their food; and some ants have learnt to 'milk' lice to get their food.)

But it is the interdependence between humans and animals that presently attracts our attention. We share much of our biology. For instance, we share $98 \%$ of our genes with chimps. By sequencing the DNA of different living species and comparing the DNA of one species with another, geneticists are able to count how many mutations have occurred since the two species diverged in the evolutionary past. By counting the mutations in the same gene in different animals, a kind of molecular clock can be drawn, where each mutation represents a tick of the clock. In the case of the chimp/human divergence, molecular evidence indicates a date between four and six million years ago (Shipman 2011:20).

In an increasingly techno-scientific oriented world, humans tend to become trans-human or posthuman, and it may just be the animal connection that can help restore our humanity. Waters (2010:197ff.) criticises this will to immortality through technology and sees finitude and mortality as part of what it means to be human. This is also the opinion of Pat Shipman in her book The animal connection. The role played by animals has seldom surfaced in thinking about what makes us human. But humans almost always exist in some connection with animals:

We adopt them, feed them, nurture them, play with them, breed them, train them, use them and eat them. We think with animals ... The connection between humans and animals has in large measure defined who and what we are as a species. (Shipman 2011:11-12) 
We now know that the domestication of animals came first, well before the domestication of plants (Shipman 2011:200).

In contrast to the positive and often idealistic history of human-animal interdependence, there is sufficient evidence of demeaning ideas and reductionist thinking, all based on ignorance. Aristotle viewed animals as incapable of any sensation but pain and hunger. The stoic, Zeno, claimed that animals felt nothing at all. For Descartes, animals were all body and no mind. Nicolas Malebranche said in his work ([1674] 1980) that animals 'eat without pleasure, cry without pain, grow without knowing it; they desire nothing, fear nothing, know nothing'. This was more or less the general view and objections from persons such as Hobbes, Spinoza and Voltaire had little impact. Darwin argued that we share physical and mental traits with other creatures. In his book on emotions The expression of the emotions in man and animals ([1871] 1965) he said that 'even insects express anger, terror, jealousy and love'. Once again these ideas were spurned. The behaviourist B.F. Skinner saw animals (and humans) as nothing but conduits of stimulus and response. Seeming evidence of higher thought among animals was an illusion (Keim 2014).

The philosopher, theologian and humanitarian Albert Schweitzer introduced a new note with the adage 'I am life that wants to live among other forms of life that want to live'. Therefore live and let live. This introduced the awareness of the interconnectedness of all life, ecological frailty and the inevitability of disaster that will follow the careless destruction of nature. Nature and culture must move closer together to regain an integrated ecological harmony. These ideas found resonance in the philosophy of holism advanced by a former South African Prime Minister, Jan Smuts.

The more recent idea of distributed identity proposed by Wesley Wildman follows the same tenor, defining human identity as complex and distributed in a variety of neurological, biological, social, ecological, cultural and axiological systems (2010:165). In the present context we are concerned about that part of our identity that includes nonhuman life, and this extends beyond our domesticated pets to all forms of life. ${ }^{1}$

We are part of the whole, and this relationship extends beyond hominids to the microbial world. It is misleading to think of human beings as a distinct species independent of environmental factors such as the microbial ocean (Wildman 2010:174).

\footnotetext{
1. Hume was one of the first philosophers to indicate that it is easy for humans to kill small insects, but this becomes increasingly difficult as the species gets bigger. We do not look an antelope in the eye and shoot it as easily as we swat a fly or step on a spider. Humans do not bond as easily with inanimate matter, insects, plants, etc. as with domesticated animals, especially pets (see Hume 1978).
}

\section{The Cambridge Declaration on consciousness $^{2}$}

Present-day sentiment favours ecological integrity, the conservation of species, animal rights, ${ }^{3}$ green or eco-theology and so on. Animal consciousness, intelligence and emotions are studied. King, Rumbaugh and Savage-Rumbaugh (1998:392) protested against a reductionist view of animal learning, which conjured up images of rats scurrying around in a maze, slowly learning their way, or Pavlovian dogs salivating in response to bells. They have indicated (King et al. 1998:383-392) various levels of animal learning from latent learning in rats to emergent learning in the multipleproblem learning of monkeys and the language proficiency of the bonobo, Kanzi. They conclude that the first traces of consciousness emerge when nervous systems 'become capable' of learning actions independent of reflex-like simplicity (King et al. 1998:392-393).

The changed view of animals culminated in the Cambridge Declaration on consciousness that was presented on 07 July, 2012 by some prominent international neuroscientists, neuropharmacologists, neurophysiologists, neuroanatomists and computational neuroscientists at the Francis Crick Memorial Conference on Consciousness in Human and nonhuman Animals, at Churchill College, University of Cambridge. The signing ceremony was screened by CBS 60 Minutes.

The declaration included the following powerful statements on human and animal consciousness and emotion:

- The field of consciousness research is rapidly evolving. Abundant new techniques and strategies for human and nonhuman animal research have been developed. Consequently, more data is becoming readily available, and this calls for a periodic revaluation of previously held preconceptions in this field. Studies of nonhuman animals have shown that homologous brain circuits correlated with conscious experience and perception can be selectively facilitated and disrupted to assess whether they are in fact necessary for those experiences. Moreover, in humans, new non-invasive techniques are readily available to survey the correlates of consciousness.

- The neural substrates of emotions do not appear to be confined to cortical structures. In fact, subcortical neural networks aroused during affective states in humans are also critically important for generating emotional behaviours in animals. Artificial arousal of the same brain

\footnotetext{
2.The Cambridge Declaration on Consciousness was written by Philip Low and edited by Jaak Panksepp, Diana Reiss, David Edelman, Bruno Van Swinderen, Philip Low and Christof Koch. The Declaration was publicly proclaimed in Cambridge, UK, on July 07, 2012, at the Francis Crick Memorial Conference on Consciousness in Human and non-Human Animals, at Churchill College, University of Cambridge, by Low, Edelman and Koch. The signing ceremony was memorialised by CBS 60 Minutes.

3.A recent example in this regard concerns Sandra, an Orang-utan, born in Germany but staying the 20 yars of her life in Bura, an Orang-utan, born in Germany but staying the last 20 years of her life in Buenos Aires. An animal-rights group (mer confirmed on 18 December 2014 that she is entitled to rights similar to those humans enjoy. This may become a precedent for the acknowledgement of more animal rights.
} 
regions generates corresponding behaviour and feeling states in both humans and nonhuman animals. Wherever in the brain one evokes instinctual emotional behaviours in nonhuman animals, many of the ensuing behaviours are consistent with experienced feeling states, including those internal states that are rewarding and punishing. Deep-brain stimulation of these systems in humans can also generate similar affective states. Systems associated with affect are concentrated in subcortical regions where neural homologies abound. Young human and nonhuman animals without neocortices retain these brain-mind functions. Furthermore, neural circuits supporting behavioural/electrophysiological states of attentiveness, sleep and decision-making appear to have arisen in evolution as early as the invertebrate radiation, being evident in insects and cephalopod molluscs (e.g. octopus).

- Birds appear to offer, in their behaviour, neurophysiology and neuroanatomy a striking case of parallel evolution of consciousness. Evidence of near human-like levels of consciousness has been most dramatically observed in African grey parrots. Mammalian and avian emotional networks and cognitive micro-circuitries appear to be far more homologous than previously thought.

- In humans, the effect of certain hallucinogens appears to be associated with a disruption in cortical feedforward and feedback processing. Pharmacological interventions in nonhuman animals with compounds known to affect conscious behaviour in humans can lead to similar perturbations in behaviour in nonhuman animals. In humans, there is evidence to suggest that awareness is correlated with cortical activity, which does not exclude possible contributions by subcortical or early cortical processing, as in visual awareness. Evidence that human and nonhuman animal emotional feelings arise from homologous subcortical brain networks provides compelling evidence for evolutionarily shared primal affective qualia.

- We declare the following: 'The absence of a neocortex does not appear to preclude an organism from experiencing affective states. Convergent evidence indicates that nonhuman animals have the neuroanatomical, neurochemical, and neurophysiological substrates of conscious states along with the capacity to exhibit intentional behaviours. Consequently, the weight of evidence indicates that humans are not unique in possessing the neurological substrates that generate consciousness. Nonhuman animals, including all mammals and birds, and many other creatures, including octopuses, also possess these neurological substrates.'

\section{Critical response to the Cambridge Declaration}

To simply state that animals have consciousness says too little. What does it mean in light of our struggle to come to terms with what human consciousness entails? There are different levels of awareness, as well as different levels of communication and expression of this awareness.
What are the consequences of this statement and are they simply applicable to all nonhuman animals? Must different species, depending on their specific level of consciousness, their ability to experience and show emotion, their history of altruistic deeds, and their display of moral traits be treated differently? Must we distinguish between different species and have a bill of animal rights in place, which can guide us in what is proper and lawful conduct in relation to specific species? How will this impact on our diet and dependence on certain animals for our food security. At what level can ethics legitimately come into play?

The statement mentions neuron firings in bonobo brains 'similar' to that of humans. This does not make the experience of bonobos the same as that of humans. Much more comes into play. Darwin indicated how humans and some animals display similar emotions often with related facial and expressions and bodily responses. This, however, does not place animal and human emotion on the same plane. Emotion is linked to reason and human reason differs drastically from that of the hominids.

Most of the statements are vague and although some similarities may be noted, differences are neglected. What is meant, for example, by the statement that 'Evidence of near human-like levels of consciousness has been most dramatically observed in African grey parrots'? The same objection is applicable. Surely, many questions can be added to those above. Nevertheless, the Cambridge statement should be noted for the specific sentiment of respect it conveys. In light of these questions, it may be good to revisit an article by Thomas Nagel.

\section{What is it like to be a bat?}

Nagel's article 'What is it like to be a bat?' (1974) drew some attention with its statement that an organism can have a conscious state only if there is something that we can relate to being that organism. Consciousness, in this view, has an essentially subjective character, a what-it-is-like aspect. This subjective aspect of consciousness cannot be captured by any familiar analysis of the mental state or by any explanatory system of functional or intentional states, since these could be ascribed to robots or automates that behaved like people though they experienced nothing.

Nagel says that it is useless to base a defence of materialism on any analysis of mental phenomena that fails to deal with their subjective character (1974:2). To use his example of the bat, bat brains are designed to correlate outgoing impulses with the subsequent echoes. But bat sonar is not similar to anything we can experience or imagine. No method will allow us to extrapolate to the inner life of the bat from our own case (Nagel 1974:2).

The question is what it was like to be a bat if one removed the viewpoint of the bat to arrive at a neutral, objective kind of understanding (1974:5). In Nagel's words, the challenge would be to describe it 'not in terms of the impressions it 
makes on our senses, but in terms of its more general effects and of properties detectable by means other than the human senses' (p. 5). But that can never be accessible to us. Our understanding of what it means to be any other species may be 'permanently denied to us by the limits of our nature' (1974:3).

The problem we are faced with is that what we perceive through our senses is already processed reality. The end product of seeing or hearing or feeling something is because of the intricate bodily processes that make this possible. But we do not have access to these processes and the processes themselves do not 'feel', 'see' or 'smell', but they issue in feeling, seeing and smelling. Nagel (1974) expresses the same sentiment when he says:

If mental processes are indeed physical processes, then there is something it is like, intrinsically, to undergo certain physical processes. What it is for such a thing to be the case remains a mystery. (p. 5)

We know by comparison. What it means to be a human can only be explained in terms of humanness. But I cannot say what it means to be a human in comparison to being a bat, a cow or a cat. I know what it means to be a hungry, or an ill or unhappy human, because I have experienced these states and can compare them to feeling satiated, healthy and sad. I can try and place myself inside your shoes, but I cannot get out of my skin to experience what it means to be a fish or a bat.

These ideas influenced contemporary philosophers and cognitive scientists who hold the following theses (Hacker 2013:50):

- An experience is a conscious experience if and only if there is something it is like for the subject of the experience to have that very experience.

- A creature is conscious or has conscious experience if and only if there is something it is like for the creature to be the creature it is.

- The subjective character of the mental can be apprehended only from the point of view of the subject.

Hacker objects to this line of thought (Hacker 2013):

From the point of view of English grammar ... there isn't anything it is like to be a bat, or to be a dolphin, and there certainly isn't anything it is like to be a human. (p. 55)

But our inquiry should surpass mere grammatical possibilities. A bat can only know what it is to be a bat if it also knows what is it like to be a bird or a flying insect. That would probably be easier to explain for the bat than to explain how being a bat compares to being a virus or, in an extreme case, to being a rock. All examples imply the presence of some form of consciousness and the ability to experience various kinds of consciousness of different species as well as the ability to compare these to each other. We know by comparison. Since this is impossible we are seemingly stuck with the 'Ding-an-sich-ness' of what it is like to be anything different from our self.
The motivation behind the excursion into Nagel's article was to make the point that humans cannot really know what it is like to be any other species, not even those closest to us. Our 'inability' to really know raises the epistemological question about the nature of our findings and inferences regarding nonhuman animal research.

\section{Language, communication, consciousness and the question of levels of awareness}

We do not really know what consciousness is. Misconceptions should first be cleared up, but this should not create the impression that we know precisely what consciousness is. The Latin conscientia is composed of scio (I know) and cum (with), which issues in the verb conscientia and the adjective conscius meaning shared knowledge or being privy to. The related word conscience refers to the internal witness (hence our idea of a guilty conscience). The meaning of being privy to something and the phrases 'conscious to oneself' and 'conscious to something' faded away to be replaced by 'being conscious of something' (Hacker 2013:18). This is the transitive use of the word. Hacker (2013:21) indicates that to become and to be conscious of something is not to perform an act of any kind. To become conscious of something is an occurrence at a given time, not something one does. It is something that happens to one. 'To be conscious of' belongs to the same family of verbs as 'notice', 'be aware of', 'realise' (Hacker 2013:22). In Hobbes' Leviathan, the idea surfaced in the context of two people knowing the same fact who are conscious of one another. From here developed the notion that to be a friend and to be conscious are similar terms (Hacker 2013:17). In order to understand animal awareness or consciousness we need to understand what human consciousness is all about.

There is transitive and intransitive consciousness. Intransitive consciousness simply denotes that you are awake (not asleep) or conscious (not comatose). Consciousness is to be awake and not asleep, aware and not unconscious, but consciousness is not equivalent to thinking. Hacker (2013:20-21) makes the important point that there is no such thing as being conscious of one's consciousness. To become and then to be conscious of something is not to perform any kind of act. To become conscious is not to pay attention to or focus on something. Neither is being conscious the act of thinking, reflecting, deciding, et cetera. Consciousness is not an activity, but something that happens to you. Consciousness is that which 'moves' across your mind, something that strikes you or something that you become aware of. Consciousness is not a form of knowledge or something you can be trained in. You can only be trained to be more receptive, sensitive (Hacker 2013:26).

To understand this, consciousness must be seen as a kind of mental apparatus like a screen on which images appear, or a stage on which actors perform. It is more a state of affairs (like being awake) than a tool you use. It is a state of awareness like a light coming on in the darkness, which 
makes you aware of your surroundings and enables you to do things. Many of the things we become aware of are made possible by our senses. I hear a noise, see a flash of light or feel pain. I cannot choose to ignore these entries upon the stage of consciousness. You do not decide to be conscious or not; you inevitably are conscious. You can choose to ignore or focus more intently on something. You are conscious of that which caught your attention, and you cannot remain conscious of something that no longer holds your attention (Hacker 2013:28). When it comes to perception, it must last some time; otherwise one could not be perceptually conscious of it. But consciousness itself is not a form of perception; it is not intentional, neither is it a form of knowledge (Hacker 2013:23, 25, 26).

Consciousness is not an inner sense with operations of the mind as its object. It is not the mark of the mind, according to Hacker (2013:47). Is consciousness an exclusive human attribute, or do we share it with other animals albeit on some basic level? Do the possessors of consciousness have, evolutionarily speaking, a better chance of survival? If so, why did consciousness not develop strongly in nonhuman animals as well? Is there a case to be made that the development of higher levels of consciousness would inevitably imply evolutionary advantage? Marian Dawkins (1993:171) reminds us that most of the things we do, we do better if we are not conscious of what we are doing. This may be applicable at the basic level of survival, but excludes all experiences associated with conscious living. Consciousness is characteristic of animals. Animals have powers of sensation and perception and are susceptible to pleasure and pain. But they do not have an inner life of reflection or articulate feeling. They are conscious, but not in the sense of being selfconscious (Hacker 2013:47, 396ff.). To move forward, we need to reconsider thinking, language and the role of emotion.

\section{Communication, language, thinking}

Is thinking possible without language, or do we think in language? If thinking is impossible without language, may animals without language still be said to think? Our thinking about thought is still under Cartesian influence, says Hacker (2013:400). We need to move beyond Descartes. The young Wittgenstein was very emphatic that thoughts do not consist of words (Hacker 2013:387). Thought is not bound to language. It comes to the fore in many guises, like desires, such as hunger, and fantasy, images and ideas. Thought may be stimulated by the senses, specific associations, and so on.

Animals do not talk, but they do communicate and think. But what is the nature of thought and thinking without language, concepts and words? What is the relation between thought and consciousness? Consciousness is possible without thought. Consciousness is linked to communication and communication to thinking and language. These and many more factors come into play when we deal with animal communication. It is the research done on bonobos and other chimpanzees in particular that has highlighted these questions.
Do animals think? Nonhuman animals can be said to think that something is so (Hacker 2013:92). Daniel Dennett (1996:12ff.) judges nonhuman animals to have mental lives. Darwin mentions how his dog responded when he went out of the house, thinking they were going for a walk and how disappointed the dog was when he turned away to the hothouse where he kept his experimental plants:

$\ldots$ and the instantaneous and complete change of expression which came over him as soon as my body swerved in the least towards the path (leading to the woods, and I sometimes tried this as an experiment) was laughable. (Darwin [1871] 1965:57ff.)

In the dog's mind there were two possibilities: either Darwin is going to the hot-house or they are going for a walk, and the dog's behaviour corresponded to the way it was thinking. In all such cases, what warrants the ascription of thinking to the animal is its behaviour. Thus, for Hacker (2013:392) the animal can think whatever it displays in its non-linguistic behaviour. Animals do not think in the sense of reflecting or ruminating. A creature can do things for a reason only in so far as it can reason (Hacker 2013:394). But animals, lacking language, cannot reason logically or illogically, or deduce a conclusion from an array of suppositions, or infer an explanation from a given datum, says Hacker. They can only recognise, associate, learn and anticipate. (2013:395).

According to Cheney and Seyfarth (2007) once we:

... accept the proposition that animals possess information about each other, objects, events and the relations between them, we commit ourselves to the existence of cognitive processes that are mediated by representational systems other than natural language. (p. 250)

Cheney and Seyfarth do not say that baboons have language or that they are capable of anything close to linguistic communication. They do, however, refer to a language of thought that has evolved in baboons and other primates. They consider this language of thought to be a general characteristic whose appearance predates the evolution of spoken language in our hominid ancestors (2007:251). But this is speculative and cannot be proven. The development of language may be the consequence of a wide range of totally different mutational and environmental factors, for example, the development of the voice box and neocortex in humans.

The experience of some form of successful communication with animals is usually very moving to humans. Shipman (2011:186) expresses it as follows: 'In that glorious instant when a human and an animal converse respectfully, appropriately, and in full awareness that a dialogue is taking place, something magical happens'. Related to this, Cheney and Seyfarth (2007:254) say that primate calls are holistic, unlike human words, which are formed by combining smaller units. Monkeys and apes almost never string different call types together in any rule-governed way. Therefore, they cannot express much more than 
what can be expressed by a single vocalisation (Cheney \& Seyfarth 2007:256). This is underscored by other researchers. Shipman (2011:179-180) refers to Barbara King, who has analysed ape communication as 'a co-regulated dance, a complex creation of meaning through body language and gesture'.

While bonobos are good at learning words through the lexigram, the larger chimpanzees struggle. For a 1971 example of a chimp, Washoe, who learnt 150 words of Ameslan (commonly used by deaf-and-dumb), see Mary Midgley's work Beast and man (1978:215); see also Fitch (2009).

The bonobo Kanzi and his agility in learning to use lexigrams to communicate has become well known. ${ }^{4}$ Lexigrams are arbitrary symbols used to communicate certain words. When Shipman (2011:180) visited the Great Ape Trust Centre, there were 384 lexigrams (symbols related to words, actions) on the touchscreen used by bonobos.

But all this must be put into context. The issue of chimptalk is complex and in spite of the excellent work done by Savage-Rumbaugh and others, a straightforward last seems to elude us. Language use cannot be severed from thinking, understanding, remembering, emotion and the like. What remains if language is taken out of the equation, or thinking or a proper memory? Critique has come from respected thinkers like Steven Pinker and Noam Chomsky (Johnson 1995:1). The bottom line is that chimps and the other higher primates lack the biological hardware required for language use. They lack the human voice box as well as the neural wiring that underlie the universal grammar that unites all languages. In spite of this and the fact that chimpanzees are not initiators of language, they do engage in dialogue once drawn into an exchange (Savage-Rumbaugh \& Brakke 1996:272)

The well-known bonobo Kanzi has acquired a vocabulary of 200 symbols by the time he was six years old and was constructing what seemed to be rudimentary sentences consisting of a word or two and a gesture. (Johnson 1995:2). Kanzi could perform certain tasks and respond to commands. But to what extent did he really understand what he was doing. What did researchers really want to prove with all of this? We know that circus animals can be trained to perform extraordinary feats. But here behaviourism and the role of the human trainer or companion comes into play, something that is absent in nature. We must also reckon with difference in abilities of individual animals that vary from each other just like humans do.

The upshot is that we know that higher primates have a rudimentary form of understanding. They have certain levels of consciousness and share many of our emotions - a fact that relates us more than that of language use.

4.For more detail on the history of Kanzi and her development, see Shipman (2011:176ff.)
Prof Nancy Howell's paper $(2014)^{5}$ is based on primate studies and challenges the way humans understand the big apes. Howell relates the history of the bonobo, Kanzi, as well as experiences linked to the language training of chimps, and proposes a new understanding of chimp communication. Language depends on gestures. Meaning emerges through intentional bodily presence. These experiences led some researchers to conclude that hominids have 'language' in the sense that they do communicate. To Howell the discussion of language is central to debates about what differentiates humans and apes. The implicit assumption is that the lack of language on the part of apes obfuscates the discussion of human uniqueness in an evolutionary perspective (Howell 2014:14). A human can be typified as homo logon egon, a being that has language. In our minds this has made us special, endowed us with soul, spirit, immortality. If you can speak or understand language and can communicate, you are human. Howell relativises the link between having language and being exclusively human. Descartes argued that the use of language was the only reliable evidence for holding a creature to be conscious of anything, and hence to have thoughts (Hacker 2013:102). We humans are not to be singled out, because apes do have 'language' according to Shipman, and when this is realised and communication takes place as it was for the first time experienced between Savage-Rumbaugh and Kanzi, this is experienced as a miraculous breakthrough similar to the experience of Hellen Keller (as dramatised in Gibson's play The miracle worker. See Shipman 2011:187).

\section{Thought in the mode of emotional awareness}

Thought, like rationality, is affected by emotion and affect. Thought may simply be the lingering in a specific mood. Humans share their limbic systems (and emotions) with many animals (the so-called mammalian brain).

5. Howell summarised her ideas and the values they entail in ten proposals. I do not discuss them separately, since the ideas she mentions that are pertinent to the

article surface in the text:
- The nature/culture divide puts humans (as subjects) over against nature (as The nature/culture divide puts humans (as subjects) over against nature (as
object). This binary kind of thinking must be abolished. We are nature, and object). This binary kind of thinking must be abolished. We are nature, and
nature deserves the same kind of respect we claim for ourselves. She challenges nature deserves the same kind of respect we claim for ourselves. She challenges
the extraordinary status of humans in light of other life forms on this planet. She criticises human exceptionalism (p. 20). Three percent of human genes are more closely related to bonobo or chimp genes than these are to each other.

- Another value is the discovery of the possibility and presence of learning and knowledge transmission in nonhuman animals, and the promise of understanding how learning occurs in bonobos and humans.

- Rob Russell predicted that 'the discovery of extra-terrestrial life will "hold a mirror up" to us and we will see someone not unlike ourselves, filled with questions like ours and beckoning to us in hopes of discovering the answers, too.' Howell wants to hold up the mirror of 'terrestrial' intelligence and culture in nonhuman species to us. We have not yet fully explored those creatures on Earth who 'hold a mirror up' to humans and have the intellectual capacity to help us see things freshly and understand life more deeply.

- A fourth value in primate studies is the fact that bonobos and chimps are in a A fourth value in primate studies is the fact that bonobos and chimps a

- The binary division of nature and culture is an unsustainable presupposition, given the evidence that language and culture are part of nature (p. 24). Nonhuman social animals might also be nature creating culture. The question is whether we can really compare the two. There are commonalities, but human culture far exceeds that of primates. The role of our biology feeling, emotion, nature of consciousness, etc. open up important philosophical and theological questions.

- She focuses on the intrinsic value of specific individuals (like Kanzi) and species (bonobos). They are beings with more than utilitarian value. They are beings with an understanding of self and relationships (2014:25). The viability of an attention epistemology (of McFague) which aims to focus one on a concrete particular being outside oneself: to listen to the other in itself, for itself (Howell p. 6).

- Panentheism. The world is God's body (McFague). God's radical immanence is to be found in the divine immanence in each creature (Howell p. 25).

- God's creativity and continuous creation stresses novelty and creativity (Howell p. 26).

- The challenge of a theological primatology (p. 26).

- Vision of the Kingdom of God (new creation). Nonhuman animals are a window to the 'Other'. Our objectifications and underestimation of them not only limits their well-being and thriving, but ours. (p. 26). 
Consequently, we share our basic emotions like fear, joy, shame, inquisitiveness, aggression, with mammals. This also explains why expressions of altruism and empathy among animals appeal to us. In isolation some of these emotions may not be so significant, but in the social context of group interaction it becomes telling. Damasio (2003) observes that in a world without emotion and feelings:

... there would have been no spontaneous exhibition of the innate social responses that foreshadow a simple ethical system - no budding altruism, no kindness when it is due, no censure when censure is appropriate, no automatic sense of one's failings. (p. 157)

Frans de Waal (2004:382) speaks of 'affective resonance' to describe the way in which the emotion or affective state of one individual impacts on that of another. The important point is that this 'affective resonance' or influencing is actively sought by a specific individual and is not simply a fortuitous by-product.

De Waal refers to experiments with mice where it was established that rats that had learnt to press a lever to obtain food would stop doing so if their response was paired with the delivery of an electric shock to a neighbouring rat in full view and hearing (De Waal 2004:384-385). With reference to bonobos, De Waal (2004) mentions that the emotional effect on the other is often actively sought and not simply the byproduct of an activity:

Thus, a rejected youngster may throw a screaming tantrum at its mother's feet, or a preferred youngster may approach a possessor of food to beg by means of sympathy-inducing facial expressions, vocalizations, and hand gestures. (p. 383)

The relation between language and emotion has been neglected and underemphasised. The role played by the social context on our behaviour, convictions, responses and so on can hardly be overestimated. We often ruminate and contemplate in a specific mood, so much so that the mood is the overriding factor and not the specifics of what we think about. In this regard one may also think of Jean Jacques Rousseau's essay 'On the origin of language' (Rousseau 1982) in which he states that the language of poets came before any other form of language:

We did not begin by reasoning but by feeling ... From where, then, could this origin derive? From the moral needs, the passions. The passions all bring men together, but the necessity of seeking their livelihood makes them flee one another. Neither hunger nor thirst, but love, hatred, pity, anger wrested the first voices from them. (p. 294)

This seems to typify the communication of the hominids. Cheney and Seyfarth (2007:218) refer to Jane Goodall, who said that chimpanzee calls are for the most part dictated by emotions: 'Whereas language is a semantic system in which words can represent thoughts, actions, and events in the world, animal communication is nothing more than the expression of emotions'. This does not imply that emotions are not semantic and cannot communicate. They do so in a very effective way. Cheney and Seyfarth (2007:228) discard the dichotomy between affective and referential signalling of animals based on the erroneous idea that only words (and not emotions) have a referential function.

\section{Creaturely theology?}

Denis Edwards (2009) believes that:

... a twenty-first century theology finds itself confronted by a human-induced crisis of the community life on Earth, and the need to develop an ecological theology that is also a theology of animals. (pp. 90-91)

The notion of creaturely theology focuses on the fact of human creatureliness. Human creatureliness cannot be thought of in separation from all other creatures sharing this planet with us. Gross (2009:136) sees animals as the vulnerable 'others' to whom humans relate. They are root others ('other' understood in Levinas' use of the word) who help us imagine ourselves and who call us to, and constitute, our being. To explain this, a moving example is given by Levinas's article 'The name of a dog; or, natural rights' discussed by Gross (2009:124-126). The story concerns 'Bobby', the name given to a dog by Jewish inmates in a concentration camp during Second World War:

The people around them, Levinas explains, 'stripped us of our human skin. We were subhuman, a gang of apes'. Bobby, however, 'would appear at morning assembly and was waiting for us when we returned ... For him, there was no doubt that we were men'. (p. 126)

In this sense Bobby called them to their being and helped to constitute it and in some sense regain it.

Creaturely theology can be seen as in line with 'green theology' or 'eco-theology' that stresses human responsibility towards the planet. A creaturely theology deals with animals as incorporated in the imago dei, animal redemption, the notion of 'deep incarnation' and so forth. It includes ethical issues like animal rights, the slaughtering of animals, farm factories, et cetera. It is an incarnational theology that '... might be extended to include kangaroos, and chimpanzees, kookaburras and dolphins' (Edwards 2009:83).

Edwards (2009:85-86) falls back on the theology of Athanasius in which God and creation meet in such a way in Christ that creation is transformed and taken into the life of God. 'The saving act of incarnation is precisely about the union of God and creation in Jesus Christ' (2009:86). Edwards (2009) then moves on to say:

The structure of Athanasius' theology can be extended today in a more explicit theology of redemption of animals'. He thus proposes that the Christ-event is saving not only for human beings, but also for other creatures, 'including dogs, horses and eagles. (p. 92)

This takes effect partially in changing human beings and their relationship to other creatures:

In the light shed by the cross, God can be understood as redemptively involved with the evolutionary history of life on Earth, and as the faithful companion of the lives and deaths of individual creatures. (Edwards 2009:94) 
In this sense Edwards comes to accept pain and suffering as an integral part of evolutionary history. It was embraced by God in Jesus' pain and suffering. 'The only way to consciousness, as far as we know, is through the flesh "that can feel its way through the world"' (Edwards 2009:94). In the Word made flesh, God embraces the whole labour of life on earth, which holds the promise that all creatures will be brought to fulfilment (Edwards 2009:95). Part of this fulfilment might be mediated by humans who, according to Edwards, live redemptively and participate in the healing of the world, through commitment to the flourishing of animals and to ethical relationships with them (Edwards 2009:98).

In similar vein, Scott (2009:174) sees nonhuman creatures as somehow included in the affirmation of the human in the incarnation. The anti-human proposes that the human cannot be considered without its attachments (animals) (Scott 2009:182). Scott also includes all creatures in the humanity of Christ and in the eschatological renewal of creation (Scott 2009:185). The positive point about Scott's anti-human approach is that he relativises the place of the human that has been asserted against all other forms of life (Scott 2009:186). This constitutes a necessary correction.

I find the idea of animal redemption problematic. The question is whether we need to 'force' an incarnational theology into accommodating nonhuman creatures in order to convince humans to care for other species. When it comes to favouring other species, the question is where do we draw the line? We seemingly favour domesticated animals and perhaps the great hominids, dolphins. Should animals displaying a lesser degree of awareness and 'consciousness' be excluded? What about the world of insects and reptiles, bacteria and viruses? We know that life on earth depends as much on the role played by bacteria as the oxygen we breathe. Where do bacteria fit into creaturely theology? We are prone to favour larger mammals with which we can relate, especially on an emotional level (see also Dawkins 1993:141ff.), whilst we are mostly unaware of microscopic life-forms that seemingly do not concern us.

\section{Animal morality?}

The idea that animals have the capacity to think or enjoy some level of awareness leads to the question of whether animals can be moral on a basic level. It all depends, says Celia Deane-Drummond (2009), on how you define morality:

But if we define morality in a much more general way as 'to judge right and wrong, good and bad, and to behave accordingly', then there is a possibility that animals might have this capacity. (p. 190)

Darwin assigns ethics a central place in human evolution in his The Decent of Man. He explicitly postulated continuity with other animals. He claims, for example, that many animals certainly sympathise with each other's distress or danger (quoted in De Waal 2004:382).
To make sense of the idea of animal morality, one has to take the social nature of animal behaviour into account, especially behaviour that can be interpreted as altruistic. In an evolutionary context someone like De Waal, for example, may judge that human morality is based on the building blocks of the social instincts of our ancestors. Part of these social instincts was the evolution of cooperative and sympathetic tendencies. It is precisely in the group context that intelligence and the possibility of higher awareness come to the fore. Dawkins (1993) refers to the fact that it is not the physical world that demands great intelligence, but the social world:

Even for early humans, finding food and shelter were relatively simple tasks compared to that of surviving in a group of other humans, in which working out who you could trust and who was likely to deceive you would become more and more complex. (p. 173)

What moral value should we attribute to these social instincts and tendencies (Deane-Drummond 2009:192-193)? Morality cannot be understood apart from intersubjectivity (Haag 2010:131ff.). Ethics is seen as 'purely and entirely a constructive and social phenomenon carried out by biological beings - it loses its relevance when isolated into a corner of psychological/biological or cultural/social assessment' (Haag 2010:140). But can we speak of intersubjectivity among the primates similar to human intersubjectivity? It was the dawning of symbolic capacities that made reasoning about our conscious experiences possible in the abstract. In the virtual realm of conscious reasoning, our experiences entangle with those of others. The conceptual juxtaposition of experiences produces a novel synergistic interaction in which the represented experience of another modifies the experience of one's own consciousness. The interactive dimension makes all the difference, since it elevates single experience to communal complexity, called intersubjectivity (Haag 2010:140). This brings Haag (2010:141) to conclude that morality arises out of the interactions of social individuals, where complexity explodes with the appearance of symbolic communication.

But we are not aware of symbolic communication among animals, and complexity should not be confused with thinking, as Dawkins (1993) aptly warns when he says:

... just because animal behaviour looks complex and could be
described by using 'mind-laden' terms like 'decision-making' or
'assessment', these should not be justified as anything more than
technical descriptions. (p. 96)

Emotion plays an important role in nonhuman primate communication and mediation, and this may be seen as the first stages of empathy. Display of emotion seemingly encourages the link to morality. Deane-Drummond (2009:196) quotes Bekoff who suggested that nonhuman animals are capable of feeling love, in the sense of preferring the company of another and protecting their interests. We know that animals show signs of grief when loved ones die. They also seem capable of showing care, even when there seems to be no advantage to them. Then there is companionship, 
joy in social play, and even the possibility that humans can learn more about forgiveness, fairness, trust and cooperation in animals, as model to live up to (Deane-Drummond 2009).

Humans do share many emotions with nonhuman animals, as Freud has indicated. This may easily deceive us into thinking that we experience love, hate, sadness, joy, and so on, in the same manner as nonhuman animals. The significant difference, however, is that human emotions are linked to human reason as human reason is linked to human emotion - something that animals lack. It is the language of love, poems on sadness, tales of compassion that colour the human world in a unique way.

Deane-Drummond believes that nonhuman animals can be thought of as in some sense sharing in moral agency (DeaneDrummond 2009:209). But what does she mean by 'in some sense'? Probably enough to prompt her to ask whether animals share in the divine image:

Specifically, we need to ask whether animals might have a religious sense, bearing in mind the gradation suggested earlier in relation to the capacity to know God. In other words, do animals have the capacity to use their reason to know God in the way that seems to be clear in human beings? (p. 209)

Deane-Drummond concludes that it would be incorrect to exclude the possibility of a form of image-bearing that is suited to particular animal species in relation to their own kinds (Deane-Drummond 2009:209). This seems to be applicable especially to 'those animals that can be regarded as our kin' (p. 210).

\section{Conclusion}

To capture the gist of the article I would like to relate a true South African story of the interaction between a young man and a baboon, which is too captivating not to share. It is the story of Jack the signalman. The story is narrated (with a photo as evidence) by Cheney and Seyfarth (2007:29-31). It took place in the late 1800s, when the Cape Government Railways opened the first line from Cape Town to Port Elizabeth. A young male employee James Wide, nicknamed Jumper because of his skill in leaping from one moving train onto another, misjudged himself, fell and lost both legs, which were amputated at the knees. He made himself a pair of pegged legs by strapping pieces of wood (looking like broom sticks) to his lower body. He was allowed to stay on in service but his job description changed to that of signalman. Jumper noticed one morning at the market place how a young baboon acted as touleier (oxen leader). Jumper persuaded the owner to give up his favourite pet, named Jack. In parting, the owner warned Jumper that Jack should be given 'a tot of good Cape brandy' every evening, otherwise he would spend the next day sulking and refuse to work. Jack soon learnt to work the signals and to listen to the blasts from the approaching locomotives. If the driver gave one, two or three blasts, Jack switched the signals in the appropriate manner. On one occasion a prominent lady travelling from Cape Town to Port Elizabeth saw to her horror that the signals in the train yard were being changed by a baboon. She reported it to disbelieving executives back in Cape Town, and did not rest until a delegation of inspectors was sent to Uitenhage. Jumper and Jack were dismissed from duty. Jumper subsequently persuaded them that he and Jack could do the job. Their skills were tested and they passed with flying colours. Jack had to be employed and both of them received daily rations and were given an official employment number.

This is an apt tale to end with because most of the issues that arise in the article also surface here: human and animal relationship, animal consciousness, emotion, thinking and emotion. Animal rights also surface, as Jack was perhaps the first animal in the world to be employed, to have an official employment number and to receive daily rations from his employer. And one can surmise that Jumper joined Jack in enjoying their daily Cape brandy each evening and having a good conversation while doing so!

Marian Dawkins (1993) captures the positive sentiment towards nonhuman animals well when she wrote:

The way in which people make moral decisions is often mysterious to me but somewhere in nearly everybody's morality, conscious beings are seen as importantly different from objects with no vestiges of consciousness. (p. 179)

Providing evidence of mental processes and the possibility of consciousness in nonhumans may make a significant difference in people's attitudes to nonhuman animals.

\section{Acknowledgements Competing interests}

The author declares that he has no financial or personal relationships which may have inappropriately influenced him in writing this article.

\section{References}

Cheney, D.L. \& Seyfarth, R.M., 2007, Baboon metaphysics. The evolution of a socia mind, The University of Chicago Press, Chicago.

Damasio, A., 2003, Looking for Spinoza. Joy, sorrow, and the feeling brain, Harvest, New York.

Darwin, C., [1871] 1965, The expression of the emotions in man and animals, University of Chicago Press, Chicago.

Dawkins, M.S., 1993, Through our eyes only? The search for animal consciousness, W.H. Freeman Spektrum, Oxford.

Deane-Drummond, C., 2009, 'Are animals moral? Taking soundings through vice, virtue, conscience and Image Dei', in C. Deane-Drummond \& D. Clough (eds.), Creaturely theology, pp. 190-210, SCM, London.

Dennett, D.C., 1996, Kinds of minds, Basic Books, New York.

De Waal, F., 2004, 'On the possibility of animal empathy', in A.S.R. Manstead, N. Frijda \& A. Fischer (eds.), Feelings and emotions, pp. 381-401, Cambridge University Press, Cambridge.

Edwards, D., 2009, 'The redemption of animals in an incarnational theology', in C. Deane-Drummond \& D. Clough (eds.), Creaturely theology, pp. 81-99, SCM, London.

Fitch, W.T.S., 2009, Why Do We Talk? BBC Horizon 10 Nov 2009 [WWW], viewed n.d., from http://www.bbc.co.uk/programmes/b00nx7n4. Accessed 12/11/2014

Gross, A.S., 2009, 'The question of the creature: Animals, theology and Levinas' dog', in C. Deane-Drummond \& D. Clough (eds.), Creaturely theology, pp. 121-37, SCM, London.

Haag, J.W., 2010, 'The emergence of morality', in N. Murphy \& C.C. Knight (eds.), Human identity at the intersection of science, technology and religion, pp. 131-143, Ashgate, Surrey. 
Hacker, P.M.S., 2013, The intellectual powers. A study of human nature, Wiley Blackwell, Oxford.

Howell, N., 2014, 'Locating nature and culture: Pan-homo culture and theological primatology', Unpublished conference paper read at a seminar organised by the Faculty of Theology at the University of Pretoria, 27-28 October 2014, Seminar theme: Ecodomy: Life in its fullness.

Hume, D., 1978, A treatise of human nature, Text revised by P.H. Nidditch, Clarendon, Oxford.

Johnson, G., 1995, 'Chimp talk debate: Is it really language?', The New York Times, Tuesday 06 June, 1995, p. 1, column 1, Science desk.

Keim, B., 2014, 'Being a sandpiper: Animals have thoughts, feelings and personality. Why have we taken so long to catch up with animal consciousness?', Aeon Magazine, 18 May, viewed n.d., from http://www.aeon.co/magazine \&www. aeon.co/video

King, J.E., Rumbaugh, D.M. \& Savage-Rumbaugh, E.S., 1998, 'Evolution of intelligence. Language, and other emergent processes for consciousness: A comparative perspective', in S.R. Hamerhoff, A.W. Kaszniak \& A.C. Scott (eds.), Towards a science of consciousness II, pp. 383-395, A Bradford Book, Cambridge, MA

Malebranche, N., [1674] 1980, The search after truth, translated from the French by T.M. Lennon and P.J. Olscamp, Ohio State University Press, Columbus.
Midgley, M., 1978, Beast and man. The roots of human nature, The Harvester Press, Hassocks, Sussex.

Nagel, T., 1974, 'What is it like to be a bat?', The Philosophical Review LXXXIII(4), 435-50.

Rousseau, J.J., 1982, 'Essay on the origin of languages and writings related to music', Collected Writings of Rousseau 7, 292-332, University Press of New England, Lebanon.

Savage-Rumbaugh, S. \& Brakke, K.E., 1996, 'Animal language: Methodology and interpretive issues', in D. Jamieson \& M. Bekoff (eds.), Readings in anima cognition, n.p., MIT Press, Cambridge, MA.

Scott, P.M., 2009, 'Slouching towards Jerusalem? An anti-human theology of rough beasts and other animals', in C. Deane-Drummond \& D. Clough (eds.), Creaturely theology, pp. 171-189. SCM, London.

Shipman, P., 2011, The animal connection. A new perspective on what makes us human, W.W. Norton \& Company, New York.

Waters, B., 2010, 'From human to posthuman theology and technology', in N. Murphy \& C.C. Knight (eds.), Human identity at the intersection of science, technology and religion, pp. 197-213, Ashgate, Surrey.

Wildman, W., 2010, 'Distributed identity: Human beings as walking, thinking, ecologies in the microbial world', in N. Murphy \& C.C. Knight (eds.), Human identity at the intersection of science, technology and religion, pp. 165-178, Ashgate, Surrey. 